\title{
Enabling the Planetary Workforce to do the best science by funding work that is a service to the Profession
}

Planetary Science 2023 Decadal Survey White paper on the State of the Profession

\section{Authors:}

Julie A. Rathbun, Planetary Science Institute (rathbun@psi.edu; she/her/hers)

Christina R. Richey, Jet Propulsion Laboratory, California Institute of Technology;

Edgard G. Rivera-Valentín, Lunar and Planetary Institute, Universities Space

Research Association

James H. Roberts, Johns Hopkins Applied Physics Laboratory

Ryan N. Watkins, Planetary Science Institute

Nicolle Zellner, Albion College

Melissa Kirven, NASA Ames REsearch Center

Co-signers:

This whute paper is submitted as part of a collaborative effort organized by the Equity, Diversity, and Inclusion Working Group (EDIWG), a cross Assessment Group (AG) committee.

As of September 15th, this paper has be co-signed by over 40 people, whose names and affiliations can be found at

https://docs.google.com/spreadsheets/d/19I0jkgNIWwwx1hJw8qEfH4 yzissCKyw gxQ9N5d4 gQ/edit?usp=sharing

We continue to accept new co-signatures. If interested, please fill out this form: https://docs.google.com/forms/d/e/1FAIpQLSea LTftvztK77vAKRkR9 qpBruofm WXc551YyddUwDNptagQ/viewform?usp=sf link 


\section{Summary}

Service work is required to keep science moving and improving. Being involved in the decadal survey process is a service to the profession. Doing work to understand the state of the profession is a service to the profession. Here, we present ways to enable these service jobs to be equitably distributed, valued, and funded in our community.

\section{Why are workforce studies and other service activities necessary?}

The Planetary Science and Astrobiology Decadal Survey Statement of Task explicitly states that the Decadal Survey "should provide a clear exposition of [...] The state of the profession including issues of diversity, inclusion, equity, and accessibility, the creation of safe workspaces, and recommended policies and practices to improve the state of the profession. Where possible, provide specific, actionable and practical recommendations to the agencies and community to address these areas" (item 9 of Statement of Task). This objective-which is listed on the same level as determining NASA's planetary science and mission priorities-is the first of its kind for a planetary science decadal survey. We applaud the NAS (and NASA and NSF) for including this important objective.

In order to understand the state of the planetary workforce, we need to study it. Workforce studies are part of the large amount of service work that takes place in our profession. Service is required to keep science moving forward and improving. We need people to review papers and proposals, organize meetings, determine science priorities, and study how we are accomplishing our work. There are many systems in place that carry out this service load: official review panels, NASA Advisory and Assessment Groups, and professional organizations (e.g., the American Astronomical Society's Division for Planetary Science; AAS DPS). There are also studies that get carried out because an individual or group sees a problem they want to address. For example, recent studies have been undertaken because questions arose regarding whether participating scientist programs benefitted mission science; if harassment was prevalent; and what typical planetary science career paths look like.

Much of the service work performed for the planetary science community is unfunded, and, therefore, unsustainable.

The vast majority of planetary scientists are funded to do scientific research. Some are also funded to teach, manage projects, support spacecraft operations, and conduct outreach activities (Hendrix, et al., 2020). Most faculty are expected to perform service work to their institution and their research community as part of their position. In some cases, faculty can be released from teaching or other responsibilities in order to commit more time to a particularly important service activity. Other institutions also fund some "overhead" or have endowments or other pools of money that can be used for writing proposals and serving on committees. However, many planetary scientists receive no explicit funding to perform service activities. Officers and members of professional organization committees (such as DPS, AAS, and sub-committees therein, e.g., Committee for the Status of Women in 
Astronomy, Committee for the Status of Minorities in Astronomy, DPS Professional Culture and Climate Subcommittee, etc.) serve without funding and thus on a volunteer basis outside of their normal work hours and responsibilities. Other service activities for which compensation is not remitted include: Advisory/Assessment Group (AG) steering committees, proposal review panels ${ }^{1}$, paper reviews, and decadal survey panels.

Generally, any funding that is provided for service activities is insufficient to support the work to perform labor intensive service activities. Furthermore, many institutions that employ planetary scientists provide no overhead funding at all, meaning that any of those scientists who do perform service activities will receive no funding for any labor they perform. The end result is that very few planetary scientists can afford to spend time performing service (including workforce climate surveys), and those who do, are often doing so at their own expense. Unpaid service work by planetary scientists is unsustainable, and should be resolved. Additionally, while some service activities need to be carried out by planetary scientists (such as proposal review panels), other activities would be better accomplished by employing experts in social science (such as demographic and harassment surveys).

\section{The planetary community has benefited specifically from many unfunded workforce studies}

There have been multiple workforce studies since the last decadal survey, including:

\begin{tabular}{|l|l|l|l|}
\hline Study: & $\begin{array}{l}\text { Study } \\
\text { lead(s): }\end{array}$ & More information: & $\begin{array}{l}\text { Was this work } \\
\text { effort funded? }\end{array}$ \\
\hline $\begin{array}{l}\text { Planetary } \\
\text { Workforce } \\
\text { Survey (White et } \\
\text { al., 2011) }\end{array}$ & $\begin{array}{l}\text { Prof. Fran } \\
\text { Bagenal }\end{array}$ & $\begin{array}{l}\text { Study to gather statistics on } \\
\text { professional planetary } \\
\text { scientists and to provide these } \\
\text { data back to NASA's Planetary } \\
\text { Science Division, to our } \\
\text { professional societies, and to } \\
\text { the community. }\end{array}$ & $\begin{array}{l}\text { Partially. AIP } \\
\text { was funded by } \\
\text { NASA PSD } \\
\text { discretionary } \\
\text { funds. Prof. } \\
\text { Bagenal and } \\
\text { other planetary } \\
\text { scientists were } \\
\text { not funded. }\end{array}$ \\
\hline
\end{tabular}

\footnotetext{
${ }^{1}$ We acknowledge that some review panelists are paid an honorarium. However, the policy is inconsistent, not clearly outlined, and the rate of pay variable. Furthermore, not all panelists (e.g., in-person vs. external) are compensated and not all panelists are allowed by their institution to accept the honorarium. A 2018 presentation (https://www.lpi.usra.edu/pac/presentations/0918/Rall.pdf) indicated that NASA R\&A reviewers receive only a modest honorarium (i.e., a few hundred $\$$ per day) and this amount had not changed in more than a decade. It also indicated that paying hourly honoraria for mission AOs improved output.
} 


\begin{tabular}{|c|c|c|c|}
\hline $\begin{array}{l}\text { CSWA Survey on } \\
\text { Workplace } \\
\text { Climate (Clancy } \\
\text { et al., 2017; } \\
\text { Richey et al., } \\
\text { 2020) }\end{array}$ & $\begin{array}{l}\text { Dr. } \\
\text { Christina } \\
\text { Richey }\end{array}$ & $\begin{array}{l}\text { This study is an internet-based } \\
\text { survey of the workplace } \\
\text { experiences of } 474 \\
\text { astronomers \& planetary } \\
\text { scientists between } 2011 \text { \& } \\
2015 \text {, looking at the inclusivity } \\
\text { of workplace climates for } \\
\text { astronomers and planetary } \\
\text { scientists. }\end{array}$ & Minimally. \\
\hline $\begin{array}{l}\text { Participating } \\
\text { Scientist } \\
\text { Programs } \\
\text { (Prockter et al., } \\
\text { 2017) }\end{array}$ & $\begin{array}{l}\text { Dr. Louise } \\
\text { Prockter }\end{array}$ & $\begin{array}{l}\text { Study of mission leadership } \\
\text { and participants in } \\
\text { participating scientist (and } \\
\text { similar) NASA programs. }\end{array}$ & No. \\
\hline $\begin{array}{l}\text { Gender on NASA } \\
\text { Spacecraft } \\
\text { Science Teams } \\
\text { (Rathbun, 2017) }\end{array}$ & $\begin{array}{l}\text { Dr. Julie } \\
\text { Rathbun }\end{array}$ & $\begin{array}{l}\text { Study of the percentage of } \\
\text { women on the science teams } \\
\text { for NASA spacecraft missions. }\end{array}$ & No. \\
\hline $\begin{array}{l}\text { Gender in } \\
\text { Authorship at } \\
\text { Astrobiology and } \\
\text { Origins of Life } \\
\text { Conferences } \\
\text { (Cabrera Salazar } \\
\text { et al., 2018; } \\
\text { Zellner et al., } \\
\text { 2019a) }\end{array}$ & $\begin{array}{l}\text { Dr. Nicole } \\
\text { Cabrera } \\
\text { Salazar, Dr. } \\
\text { Nicolle } \\
\text { Zellner }\end{array}$ & $\begin{array}{l}\text { Study to gather statistics on } \\
\text { who speaks at Astrobiology } \\
\text { and Origins of Life conferences } \\
\text { and to provide these data } \\
\text { back to conference organizers, } \\
\text { to our professional societies, } \\
\text { and to the community. }\end{array}$ & $\begin{array}{l}\text { Partially: } \\
\text { Zellner's } \\
\text { institution } \\
\text { provided partial } \\
\text { funding to } \\
\text { co-authors and } \\
\text { students only, for } \\
\text { data mining, data } \\
\text { analysis, and } \\
\text { some writing }\end{array}$ \\
\hline $\begin{array}{l}\text { Gender in LPSC } \\
\text { Authorship } \\
\text { (Zellner et al, } \\
\text { 2019b, 2020) }\end{array}$ & $\begin{array}{l}\text { Dr. Nicolle } \\
\text { Zellner }\end{array}$ & $\begin{array}{l}\text { Study to gather statistics on } \\
\text { who speaks at the annual } \\
\text { Lunar and Planetary Science } \\
\text { Conferences and to provide } \\
\text { these data back to conference } \\
\text { organizers, to our professional } \\
\text { societies, and to the } \\
\text { community. }\end{array}$ & $\begin{array}{l}\text { Partially: } \\
\text { Zellner's } \\
\text { institution } \\
\text { provided partial } \\
\text { funding to } \\
\text { co-authors and } \\
\text { students only, for } \\
\text { data mining, data } \\
\text { analysis, and } \\
\text { some writing }\end{array}$ \\
\hline $\begin{array}{l}\text { DPS Planetary } \\
\text { Workforce }\end{array}$ & $\begin{array}{l}\text { Dr. } \\
\text { Amanda }\end{array}$ & $\begin{array}{l}\text { Study to gather statistics on } \\
\text { planetary scientists and to }\end{array}$ & $\begin{array}{l}\text { Partially. AIP } \\
\text { was funded by }\end{array}$ \\
\hline
\end{tabular}




\begin{tabular}{|l|l|l|l|}
\hline $\begin{array}{l}\text { Survey (Hendrix, } \\
\text { et al., 2020) }\end{array}$ & $\begin{array}{l}\text { Hendrix, } \\
\text { Dr. Julie } \\
\text { Rathbun }\end{array}$ & $\begin{array}{l}\text { provide these data back to the } \\
\text { community and influence the } \\
\text { Planetary and Astrobiology } \\
\text { Decadal Survey. }\end{array}$ & $\begin{array}{l}\text { DPS. No } \\
\text { planetary } \\
\text { scientists were } \\
\text { funded. }\end{array}$ \\
\hline $\begin{array}{l}\text { The Role of the } \\
\text { Next Generation } \\
\text { Lunar Scientists } \\
\text { (NextGen) Group } \\
\text { in Lunar Science } \\
\text { and Exploration } \\
\text { (Clegg-Watkins et } \\
\text { al., 2015) }\end{array}$ & $\begin{array}{l}\text { Dr. Ryan } \\
\text { Watkins } \\
\text { and the } \\
\text { Organizing } \\
\text { Committee }\end{array}$ & $\begin{array}{l}\text { Two studies aimed at gauging } \\
\text { participation and } \\
\text { demographics of lunar } \\
\text { scientists who identify as early } \\
\text { career and who participate in }\end{array}$ & $\begin{array}{l}\text { NextGen-sponsored } \\
\text { workshops. }\end{array}$ \\
\hline $\begin{array}{l}\text { Surveys from the } \\
\text { NASA } \\
\text { Astrobiology } \\
\text { Program }\end{array}$ & $\begin{array}{l}\text { Dr. Melisa } \\
\text { Kirven- } \\
\text { Brooks }\end{array}$ & $\begin{array}{l}\text { This will be a series of surveys } \\
\text { of the astrobiology community } \\
\text { to gather baseline } \\
\text { demographics and attitudinal } \\
\text { data and ultimately to assess } \\
\text { whether gender, race or other } \\
\text { factors have an impact on } \\
\text { research careers. }\end{array}$ & \\
\hline
\end{tabular}

Here, we pose three questions:

1. How have studies of the state of the planetary science profession been initiated?

2. How has data collection and analysis been funded?

3. How can this be sustainable for the future?

How have past studies about the state of the planetary science profession been initiated?

Most studies of the planetary science workforce, including those mentioned above, have generally been initiated by individual community members who were passionate about the question they were asking. There has been little oversight or community consensus on what studies to perform. We note that these studies were led by self-identified women, who disproportionately take on the unfunded service work in the community.

\section{How has data collection and analysis been funded?}

Several of the studies were unfunded or only partially funded (see table above). Even when funding was obtained, generally it relied upon individuals understanding non-obvious sources of money, such as discretionary funds. So, which projects were funded and/or completed depended on a project having a "champion" who was able to volunteer their time, had access to funding not accessible by everyone, and was knowledgeable about the structures that exist in 
planetary and other sciences. This system is neither sustainable nor inclusive nor the best use of resources and talent.

The use of the American Institute of Physics (AIP) also illustrates an important point about having experts working on studies. The AIP Statistical Research Center collects, analyzes and disseminates data on education, careers, and diversity in physics, astronomy and other physical sciences. The senior staff consists of statisticians and other social scientists who are experts in collecting and analyzing data from surveys and other sources.

\section{Making a diverse planetary community}

One of the major goals of many of the above listed studies is to make the planetary science community more diverse and inclusive. NASA shares these goals, which is explicitly stated in all high-level NASA strategic documents. The NASA Science Vision (Science 2020-2024: A Vision for Scientific Excellence) identified "Increase the diversity of thought and backgrounds represented across the entire SMD portfolio through a more inclusive environment" as one of its top priorities (Strategy 4.1). The 2018 NASA Strategic Plan identified "Cultivate a diverse and innovative workforce with the right balance of skills and experience to provide an inclusive work environment in which employees that possess varying perspectives, education levels, life experiences, and backgrounds can work together and remain fully engaged in our mission" as one of its top objectives (Strategic Objective 4.4). It could be argued that diversity, equity, and inclusion are more central to NASA's goals than almost any one particular planetary science investigation. For example, "diversity" is mentioned 7 times in Science Vision and 10 times in the Strategic Plan. In contrast, Europa is mentioned once in the Science Vision and omitted from the Strategic Plan.

While NASA funds programs that help advance their scientific and exploration goals, including instrument design and scientific research, they generally do not fund studies of and service to the planetary science community despite a clearly defined goal to support a sustainable and diverse workforce. Furthermore, NASA exerts no influence on how and which questions are addressed by planetary scientists. Finally, NASA does not require funded science (e.g, SSERVI Solar System Exploration Research Institute) or mission teams to demonstrate competency or progress with respect to diversity and inclusion metrics.

\section{Recommendations for sustainability}

In order for NASA to reach its diversity and inclusion goals, to ensure that underrepresented groups are not volunteering time disproportionately, and ensure that science keeps moving forward, we recommend that NASA begin funding studies of and service to the planetary science community by implementing the following:

Recommendation \#1: NASA should make additional funding for service work available to scientists already supported by NASA grants. This could be implemented by adopting a model similar to the old Education and Public Outreach (EPO) model. If a researcher has another NASA grant, they can write a grant for 
additional monies to support service work. Another possibility is for NASA to simply add a 5-10\% overhead for each PI to engage in service work and require scientists to report their activities in their annual reports. Yet another possibility is to follow the NSF example of "broader impacts" which increase the scope of work of the grant to include service work.

Recommendation \#2: NASA should create a new R\&A program to fund workforce studies and other activities that address NASA's strategic goals of equity, diversity, and inclusion. There is a precedent to this type of funding as Dr. Julie Rathbun is currently funded for diversity studies through an unsolicited grant. A competed process would enable peer-review to determine the most important work to accomplish. It would also lead to a wider range of ideas as it would be open to all and not just those with insider knowledge. The program should be at the Science Mission Directorate (SMD) level (similar to call E.2 of the 2020 ROSES).

Recommendation \#3: NASA should create positions within SMD for social scientists to study the planetary workforce and related NASA programs. The Space Telescope Science Institute has worked with social scientists to analyze data and advise on ways to mitigate implicit bias. NASA should create a position(s) for social scientists to study the planetary science (and other) communities and advise on ways to mitigate against biases and make the workforce more diverse and workplaces more equitable.

Recommendation \#4.1: NASA should find a way to financially compensate all members of AG steering committees and proposal reviewers for their time. Recommendation \#4.2: NASA or NASEM should find a way to financially compensate members of decadal survey panels.

Without funding, the above groups will not accurately reflect the planetary science community and will include disproportionate representation of faculty and planetary scientists at institutions with larger amounts of discretionary funds. And yet, these groups are actively involved in determining what science gets done and by whom. When these groups are not inclusive or diverse, neither are their decisions, conclusions, or recommendations. We note that a stipend or honorarium may not be the best way to accomplish these payments since some organizations do not permit their employees to accept honorariums or stipends from outside sources, so other compensation mechanisms should be developed.

Recommendation \#6: NASA and/or NSF should create a funding line for AIP to administer surveys of the planetary workforce every 5 years, timed to be used as input into each planetary decadal survey. The first survey of the planetary workforce was undertaken in 2011 and AIP's contribution was funded by NASA's PSD. The next survey was performed in 2020 to assist with the Decadal Survey and was funded by the DPS. Since the survey is commissioned by NASA (and the NSF) and a survey is necessary to determine the state of the workforce, NASA (and the NSF) should fund the survey. NASA is already funding planetary mission concept 
studies for this current decadal survey and they could use a similar process to fund the AIP in the future. Funding of AIP for performing the survey requires an amount that is minimal in comparison to typical NASA grant sizes and thus would be feasible to maintain even in difficult funding situations.

\section{Recommendation \#6.1: NASA and/or NSF should fund the AIP to complete the analysis of the 2020 Planetary Workforce Survey commissioned by the DPS. While the DPS was able to fund the development and basic analysis of the survey (https://dps.aas.org/reports), the final two questions in the survey were open-ended (not multiple choice), which require more work to analyze (Hendrix, et al., 2020). These two questions were about factors which either enabled or were a barrier to success in planetary science. It is crucial that the decadal survey use the results of this analysis in their deliberations and final report.}

\section{References}

Cabrera Salazar et al. (2018) Look who's talking: An investigation of gender representation at Astrobiology meetings, Maria Mitchell Women in Science Symposium, Wellesley, MA

Clancy K. B. H., Lee K. M. N., Rodgers E. M., Richey C. (2017) Double Jeopardy in Astronomy and Planetary Science: Women of Color Face Greater Risks of Gendered and Racial Harassment, Journal of Geophysical Research: Planets 122: $1610-1623$

Clegg-Watkins et al. (2015), https://www.hou.usra.edu/meetings/leag2015/pdf/2017.pdf

Hendrix, A.R. et al. (2020). The state of the planetary science community: Results from the 2020 DPS survey. Lunar and Planetary Science Conference, id.2813. https://www.hou.usra.edu/meetings/lpsc2020/pdf/2813.pdf and white paper to this decadal survey

Prockter, et al. (2017) The Value of Participating Scientist Programs to NASA's Planetary Science Division, https://www.lpi.usra.edu/analysis/reports/Value of Participating Scientist Programs to NASA white paper final.pdf

Rathbun (2017) Participation of women in spacecraft science teams, Nature Astronomy, 1.

Richey et al. (2020) Gender and sexual minorities in astronomy and planetary science face increased risks of harassment and assault, BAAS, https://baas.aas.org/pub/2019i0206/release/1

White S., Chu R. Y. and Ivie R. (2015) 2011 Survey of the Planetary Science Workforce, http://lasp.colorado.edu/home/mop/files/2015/08/Report.pdf

Zellner et al. (2019a) Investigating Gender Representation at Astrobiology Meetings, Astrobiology Science Conference, Belleville, WA, ID \#481235

Zellner et al. (2019b) LPSC @ 50: What do 18 Years of Presentation Data Tell Us?, 50th Lun. Plan. Sci. Conf., The Woodlands, TX, March, 3024.pdf

Zellner et al. (2020) 18 Years of LPSC Attendance and Presentation Data: Who's Included?, 51st Lun Plan Sci Conf, 1738.pdf. 